\title{
Pigeons (l'habit de fait pas le moine)
}

Pigeons (l'habit de fait pas le moine) shows the deviations that could provide a non-ecological world.

Beautiful tropical birds have lost their flamboyant colors. The colorful dresses of those birds become gray as the well-known sad pigeons.

The installation also speaks of a perspective between different cultures and offers a reflection on the vision that we have of each other.

The exoticism is a concept that depends on where you are.

\section{About the Artist}

Rafaela Lopez was born in 1988 in Paris and currently lives and works in London. In 2009, she studied at the Arts Décoratifs in Paris. In 2013, she graduated from the art school of the Villa Arson (Nice) and is continuing her studies in the Sculpture Department of the Royal College of Art (London). She has participated in many exhibitions such as the Salon de Montrouge (curated by Stéphane Corréard, Le Befrroi, France), Heart of Darkness (curated by Julien Bouillon and Richard Wentworth, Art Centre of the Villa Arson, Nice), and Les Corps Compéents (curated by Arnaud Labelle-Rojoux, CNAC, France). Lopez also has a curating practice.

\section{ON THE COVer}

Pigeons (l'habit ne fait pas le moine) (2013) by Rafaela Lopez. Acrylic painting on wood sculptures, variable dimensions. Private collections, France and UK. This artwork won the first place in the 2014 EcoHealth Journal Cover Art Competition.
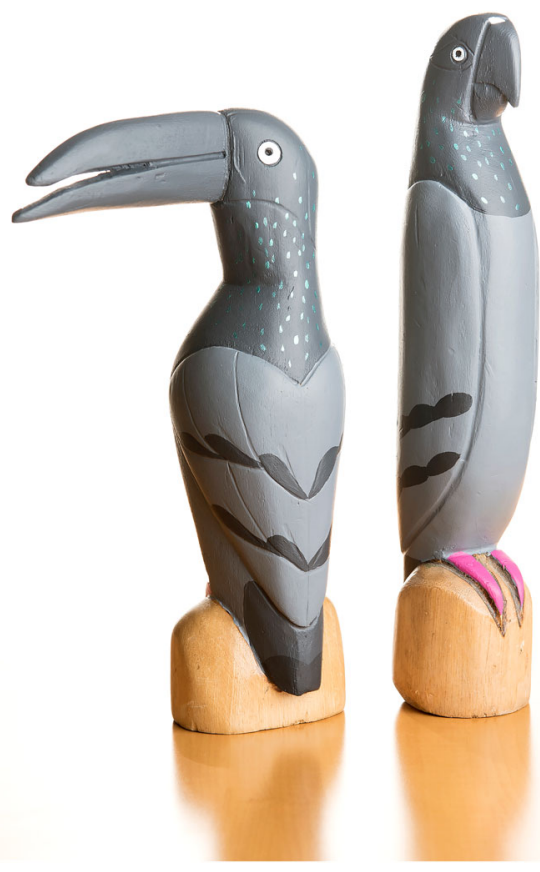